\title{
BMJ
}

\section{Diagnostic accuracy of urinary spot protein:creatinine ratio for proteinuria in hypertensive pregnant women: systematic review}

\begin{abstract}
Anne-Marie Côté, obstetric medicine fellow, ${ }^{1}$ Mark A Brown, professor of medicine, ${ }^{2}$ Elaine Lam, medical student, ${ }^{1}$ Peter von Dadelszen, associate professor of obstetrics and gynaecology, ${ }^{3}$ Tabassum Firoz, resident internal medicine, ${ }^{1}$ Robert $M$ Liston, professor and chair in obstetrics and gynaecology, ${ }^{3}$ Laura A Magee, clinical associate professor of medicine ${ }^{3}$
\end{abstract}

\begin{abstract}
'BC Women's Hospital and Health Centre, Vancouver, BC, Canada

${ }^{2}$ St George Hospital and University of New South Wales, Kogarah, Sydney, NSW, Australia

${ }^{3}$ Child and Family Research Institute, University of British

Columbia, Vancouver, BC, Canada V6H 3N1

Correspondence to: $\mathrm{L}$ A Magee, $\mathrm{BC}$ Women's Hospital and Health

Centre, Vancouver, BC, Canada V6P158 LMagee@cw.bc.ca
\end{abstract}

doi:10.1136/bmj.39532.543947.BE pre-eclampsia. As such, assessing the presence or

Urine collection over 24 hours is considered the

\section{ABSTRACT}

Objective To review the spot protein:creatinine ratio and albumin:creatinine ratio as diagnostic tests for significant proteinuria in hypertensive pregnant women.

Design Systematic review.

Data sources Medline and Embase, the Cochrane Library, reference lists, and experts.

Review methods Literature search (1980-2007) for articles of the spot protein:creatinine ratio or albumin: creatinine ratio in hypertensive pregnancy, with 24 hour proteinuria as the comparator.

Results 13 studies concerned the spot protein:creatinine ratio (1214 women with primarily gestational hypertension). Nine studies reported sensitivity and specificity for eight cut-off points, median $24 \mathrm{mg} / \mathrm{mmol}$ (range $17-57 \mathrm{mg} / \mathrm{mmol}$; 0.15-0.50 mg/mg). Laboratory assays were not well described. Diagnostic test characteristics were recalculated for a cut-off point of $30 \mathrm{mg} / \mathrm{mmol}$. No significant heterogeneity in cut-off points was found between studies over a range of proteinuria. Pooled values gave a sensitivity of $83.6 \%$ ( $95 \%$ confidence interval $77.5 \%$ to $89.7 \%$ ), specificity of $76.3 \%$ (72.6\% to $80.0 \%$ ), positive likelihood ratio of 3.53 (2.83 to 4.49), and negative likelihood ratio of 0.21 ( 0.13 to 0.31 ) (nine studies, 1003 women). Two studies of the spot albumin:creatinine ratio (225 women) found optimal cut-off points of $2 \mathrm{mg} / \mathrm{mmol}$ for proteinuria of $0.3 \mathrm{~g} /$ day or more and $27 \mathrm{mg} / \mathrm{mmol}$ for albuminuria.

Conclusion The spot protein:creatinine ratio is a reasonable "rule-out" test for detecting proteinuria of $0.3 \mathrm{~g} /$ day or more in hypertensive pregnancy. Information on use of the albumin:creatinine ratio in these women is insufficient.

\section{INTRODUCTION}

Providers of obstetric care must be familiar with the diagnosis of pre-eclampsia, the hypertensive condition associated with the highest risk of adverse maternal and perinatal complications and a condition that affects 2 $5 \%$ of pregnancies. ${ }^{12}$ Inclusion of the end organ complications of pre-eclampsia in its definition is controversial. It is, however, agreed that women with gestational hypertension and new proteinuria have absence of significant proteinuria $(\geq 0.3 \mathrm{~g} /$ day $)$ represents a key component in the evaluation of pregnant women with hypertension by providers of obstetric care and researchers. traditional comparator for quantification of proteinuria in pregnancy, when significant proteinuria is defined as proteinuria of $0.3 \mathrm{~g} /$ day or more. ${ }^{1-4}$ The urine requires refrigeration and its collection is cumbersome, time consuming (for women and ward staff), and potentially misleading if collected inaccurately. Also, it may not be possible to complete the urine collection when delivery occurs, leading to undetermined proteinuria status and an unsubstantiated diagnosis of pre-eclampsia; less than half of women admitted with pre-eclampsia have a 24 hour urine collection sent for analysis. ${ }^{15}$ Timed collections delay clinical diagnosis and may result in prolonged hospital stay when a hypertensive disorder of pregnancy is being investigated, thereby increasing patient anxiety and healthcare costs.

Because of the disadvantages of 24 hour urine collection, alternatives for the diagnosis of proteinuria in pregnancy have been considered. These include urinary dipsticks, urine collections over a shorter period, the urinary spot protein:creatinine ratio, and the urinary spot albumin:creatinine ratio. The dipstick is inexpensive, easy to use, and provides a rapid result but has been shown to have low sensitivity and specificity for urinary protein excretion over 24 hours. ${ }^{6-10}$ A few studies (and guidelines from the national high blood pressure education programme ${ }^{1}$ ) have proposed using shorter timed urine collections (two, four, eight, or 12 hours) to diagnosis proteinuria in pregnancy. ${ }^{11-15}$ Shorter collections, however, share some of the limitations and concerns associated with 24 hour collection

The spot protein:creatinine ratio and spot albumin: creatinine ratio have been well studied and used 
outside pregnancy. The National Kidney Foundation now recommends these tests (instead of 24 hour urine collection) to diagnose proteinuria in most situations, without specific mention of pregnancy. ${ }^{16}$ The Australasian Society for the Study of Hypertension in Pregnancy and the International Society for the Study of Hypertension in Pregnancy have proposed use of the urinary spot protein:creatinine ratio as an alternative to 24 hour urine collection. ${ }^{34}$ It is our impression that the spot protein:creatinine ratio is not widely used for the diagnosis of proteinuria in pregnant women with hypertension.

We carried out a systematic review to assess the accuracy of the spot protein:creatinine ratio and spot albumin:creatinine ratio compared with 24 hour urinary collection for the detection of significant proteinuria in hypertensive pregnant women.

\section{METHODS}

We searched Medline and Embase (January 1980 to May 2007) using the keywords "spot protein-creatinine", or "protein-to-creatinine ratio", or "spot albumin-creatinine", or "albumin-to-creatinine ratio", or "24-hr albumin collection", or "microalbuminuria", or "urinary microalbumin", or "24-hour urine collection", or "proteinuria", and the subject headings of "pregnancy", "preeclampsia", or "toxemia". The dataset was limited to "human and female". We began the search from 1980 because the spot protein: creatinine ratio and albumin:creatinine ratio were not used before this time. Other sources included the Cochrane Library, reference lists of both primary articles and national and international guidelines for pregnancy hypertension, and personal communication with experts in the discipline.

We included diagnostic studies that compared the urinary spot protein:creatinine ratio or albumin: creatinine ratio with urinary protein excretion over 24 hours (24 hour proteinuria), among pregnant women with hypertension (at least $80 \%$ of the study population). We excluded studies that evaluated the spot protein:creatinine ratio in women with medical conditions other than hypertension (predominantly diabetes mellitus), used a reference test other than the 24 hour urine collection (including 24 hour protein: creatinine ratio), were written in languages other than English or French, or were only in abstract form.

\section{Validity assessment}

As we are not aware of a published validated score for assessing the quality of diagnostic test studies, we used the number of standardised criteria met by each paper on the QUADAS (quality assessment of studies of diagnostic accuracy in systematic reviews) tool. ${ }^{17}$

\section{Data abstraction and study characteristics}

Two reviewers independently abstracted the data (AMC and EL, or AMC and $\mathrm{LM}$ ) and disagreements were resolved by consensus. We recorded characteristics of the study (authors, journal, year of publication, country, study design, objectives, type of medical centre, and period or duration of the study); characteristics of the participants (study population, method of selection, inclusion and exclusion criteria, whether consecutive cases, number of participants, number of excluded participants and reasons for exclusion, personal and medical characteristics of enrolled women, inpatients compared with outpatients, level of activity); information on how the diagnostic tests were carried out and the results (timing of spot protein: creatinine ratio or albumin:creatinine ratio compared with 24 hour urine collection, method of assessment for the completeness of 24 hour urine collection, number of incomplete collections, prevalence of significant proteinuria, range of proteinuria, laboratory methods for measurement of protein and creatinine, and results of diagnostic test); and methods for assessing the diagnostic accuracy of the tests and the results (sensitivity, specificity, positive likelihood ratio, negative likelihood ratio, method of agreement (for example, Bland-Altman plots), receiver operating characteristic curve, area under the curve, and the proposed diagnostic cut-off point for significant proteinuria, using a conversion factor of 1.13 to transform results for the spot protein:creatinine ratio reported in $\mathrm{mg}$ protein $/ \mathrm{mg}$ creatinine into SI units of $\mathrm{mg} / \mathrm{mmol})$. When positive and negative likelihood ratios were not available we calculated them from sensitivity and specificity as follows: positive likelihood ratio $=$ sensitivity $/(1-$ specificity $)$ and negative likelihood ratio $=(1-$ sensitivity $) /$ specificity. We did not abstract correlation coefficients or predictive values (positive and negative), as correlation coefficients do not reflect agreement between two methods and predictive values vary according to prevalence of the studied condition. We contacted authors for missing information.

\section{Quantitative data synthesis}

For each study we descriptively analysed sensitivity, specificity, likelihood ratios, and area under the curve for the receiver operating curves, according to reported cut-off points. To explore whether diagnostic accuracy differed significantly between studies we chose a cut-off point of $30 \mathrm{mg}$ protein $/ \mathrm{mmol}$ creatinine. ${ }^{3}$ From data provided in the body of the articles, tables or graphs, we used contingency tables to recalculate the diagnostic test characteristics of sensitivity, specificity, and likelihood ratios for as close to a cut-off point of $30 \mathrm{mg} /$ mmol as possible. When the prevalence of significant proteinuria was unavailable, we used the median prevalence from the published studies to generate contingency tables.

To allow for variation in diagnostic threshold we assessed statistical heterogeneity between studies using the Littenberg and Moses regression method. ${ }^{18}$ In the absence of heterogeneity, we calculated new measures of diagnostic accuracy using data from each study $i$ as follows: sensitivity $\mathrm{i}_{\mathrm{i}}=$ true $_{\text {positive }} /$ disease present $_{\mathrm{i}}$; specificity $_{\mathrm{i}}=$ true negative $_{\mathrm{i}} /$ disease absent $_{\mathrm{i}}$; pooled sensitivity $=\Sigma$ true positive $\mathrm{i}_{\mathrm{i}} / \Sigma$ disease present $\mathrm{i}_{\text {; }}$, pooled specificity $=\Sigma$ true negative $\mathrm{i}_{\mathrm{i}} / \Sigma$ disease absent $\mathrm{i}_{\mathrm{i}}$; standard 
error of a proportion=[proportion $(1-$ proportion $) /$ $\left.\Sigma \mathrm{n}_{\mathrm{i}}\right]^{1 / 2}$; pooled positive likelihood ratio=pooled sensitivity/(1-pooled specificity); and pooled negative likelihood ratio $=(1-$ pooled sensitivity $) /$ pooled specificity. ${ }^{18}$ We carried out sensitivity analyses by excluding studies when they differed methodologically from all or most others (for example, study population or method for collection of urine samples).

Analyses were carried out using Microsoft Excel (2002) and GraphPad PRISM 4 software.

\section{RESULTS}

The electronic search yielded 1416 citations (figure). One publication, on the spot protein:creatinine ratio, was not in English or French and was excluded. ${ }^{19}$ Twenty four studies were retrieved for further examination. These included 13 studies on the spot protein: creatinine ratio (1214 women $)^{\mathrm{w} 1-13}$ and two on the spot albumin:creatinine ratio ( 225 women), ${ }^{\mathrm{w} 14} \mathrm{w} 15$ published between 1996 and 2007. Nine studies were excluded because they enrolled a mixed population of pregnant women who were not primarily hypertensive $(n=$ 3), ${ }^{20-22}$ enrolled only women with proteinuria, ${ }^{23}$ overlapped with a more recent included study, ${ }^{24}$ evaluated the spot protein:creatinine ratio from a timed collection $(\mathrm{n}=1),{ }^{25}$ reported only on the correlation between the spot albumin:creatinine ratio and 24 hour urinary albumin, ${ }^{2627}$ or did not study the protein:creatinine ratio or albumin:creatinine ratio. ${ }^{28}$ No additional articles were retrieved after examining reference lists and contacting experts.

Spot protein:creatinine ratio

Validity assessment

The quality assessment score ranged from 7 to 12

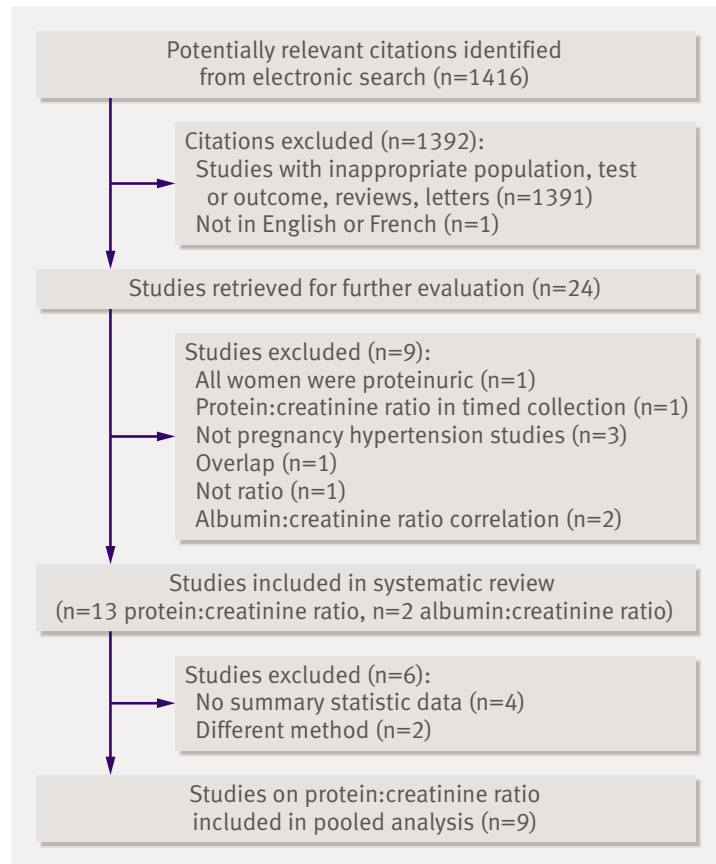

Flow of studies through systematic review (table 1$)^{17}$; lower scores reflect mainly an incomplete description of the selection criteria, spectrum of disease, or how the diagnostic test was executed. Most of the studies were prospective $(n=10)$ and cross sectional $(\mathrm{n}=11)$. None mentioned how many women of those eligible were enrolled, and only two stated recruitment of consecutive, eligible women. ${ }^{\mathrm{w} 3 \mathrm{w} 13}$ Ten studies stated reasons for withdrawals or exclusion

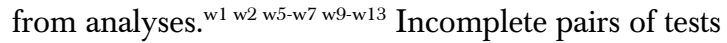
for analysis ranged from 11-32\% of samples. ${ }^{\text {w1 }}$ w4 w10 w12 ${ }^{\text {w13 }}$ Reasons stated for incomplete collections included inadequate collection procedures and delivery.

\section{Characteristics of studies and participants}

Studies of the spot protein:creatinine ratio analysed samples from 30-220 women (median 75). The women had gestational hypertension (five studies), gestational hypertension with proteinuria of + or more (suspected pre-eclampsia; $n=5)$, or any hypertensive disorder of pregnancy $(n=3)$. Ten studies enrolled women admitted to hospital. Two studies excluded women who needed bed rest. ${ }^{11 \text { w13 }}$ Six studies excluded women with underlying medical disease such as preexisting hypertension, diabetes, or renal disease ${ }^{\mathrm{w} 1 \mathrm{w} 2 \mathrm{w} 5}$ w7 w9 w12 and six excluded women with urinary tract infection or bacteriuria. ${ }^{\text {w1 } w 6 \text { w7 w9 w11 w12 }}$

\section{Diagnostic tests}

The prevalence of significant proteinuria $(\geq 0.3 \mathrm{~g} /$ day $)$ varied from $21 \%$ to $83 \%$ (median $55 \%, \mathrm{n}=11$; table 2 ). The range of 24 hour proteinuria varied from normal to nephrotic: 0-26.5 g/day ( $\mathrm{n}=11)$. Ranges for the spot protein:creatinine ratio varied from $0-2991 \mathrm{mg} / \mathrm{mmol}$ $(\mathrm{n}=9)$.

The timing of the spot protein:creatinine ratio relative to 24 hour urine collection varied: before $(n=9)$, after $(n=1)$, before or after $(n=1)$, or during $(n=2)$. Nine studies stated that the spot protein:creatinine ratio was not based on the first voided sample of the day. ${ }^{\text {w1 w3 }}$ w6-w9 w11-w13 In four studies, completeness of the 24 hour urine collection was assessed by urinary creatinine excretion $^{\mathrm{w} 1 \mathrm{w} 5 \mathrm{w} 10 \mathrm{w} 11}$ or by questioning the women. ${ }^{\mathrm{w} 13}$ In one study, urine was collected by a Foley catheter in $89 \%(196 / 220)$ of the women because of vaginal bleeding (post partum), active labour, or treatment with magnesium sulphate. ${ }^{\text {w2 }}$

Urinary protein and creatinine were measured by many different laboratory methods (various reagents, manual or automated methods). At least five analytical methods were used for protein (Biuret, ${ }^{\text {w2 w4 w11 }}$ pyro- $^{-}$ gallol red reaction, ${ }^{\mathrm{w} 6 \mathrm{w} 7 \mathrm{w} 10 \mathrm{w} 12 \mathrm{w} 13}$ sulphosalicylic acid, ${ }^{\mathrm{w} 5}$ trichloroacetic acid, ${ }^{w 1}$ w9 turbimetric method (not specified), ${ }^{\mathrm{w} 3}$ and benzethonium chloride ${ }^{\mathrm{w} 8}$ ) and at least two were used for creatinine (modified Jaffé, two point rate method, ${ }^{\text {w1-w5 }}{ }^{\text {w7-w13 }}$ and iminohydrolase reactions $\left.{ }^{\mathrm{w} 6}\right)$.

\section{Diagnostic test results}

Two studies reported only correlation coefficients and are excluded from table $3 .^{\mathrm{w} 3 \mathrm{w} 4}$ The area under the curve was reported by nine of the 11 remaining studies 
Table 1 | Study and population characteristics of hypertensive pregnant women with urine assessed by spot protein:creatinine ratio

\begin{tabular}{lccccc} 
Study & $\begin{array}{c}\text { No women* } \\
\text { (No analysed) }\end{array}$ & $\begin{array}{c}\text { Patient status } \\
\text { of women }\end{array}$ & $\begin{array}{c}\text { Type of hypertensive } \\
\text { disorder of pregnancy } \\
\text { included }\end{array}$ & $\begin{array}{c}\text { Gestational } \\
\text { age (weeks) }\end{array}$ & Exclusions \\
Al et al $2004^{\mathrm{w1}}$ & $221(185)$ & Inpatients & Gestational hypertension & $\geq 29$ & $\begin{array}{l}\text { Urinary tract infection or } \\
\text { chronic medical illness, } \\
\text { severe hypertension }\end{array}$ \\
\hline
\end{tabular}

\begin{tabular}{lllll}
\hline $\begin{array}{l}\text { Durnwald et al } 220 \quad \text { Inpatients } \\
2003^{\text {w2 }}\end{array}$ & $\begin{array}{l}\text { Suspected pre-eclampsia } \\
\text { (gestational hypertension, } \\
\text { oedema, or new + or more } \\
\text { proteinuria) } \dagger\end{array}$ & Chronic medical illness*
\end{tabular}

\begin{tabular}{lclllll}
\hline $\begin{array}{l}\text { Jaschevatzky et } \\
\text { al } 1990^{\text {w3 }}\end{array}$ & 35 & Inpatients & $\begin{array}{l}\text { Pre-eclampsia (gestational } \\
\text { hypertension, oedema, or } \\
\text { new proteinuria) }\end{array}$ & NS & 8 \\
\hline $\begin{array}{l}\text { Neithardt et al } \\
36(30)\end{array}$ & Inpatients & Any hypertensive disorder of & Any & NS
\end{tabular}

\begin{tabular}{lllll}
\hline $\begin{array}{l}\text { Neithardt et al } \\
2002^{\text {w4 }}\end{array}$ & $36(30)$ & Inpatients & $\begin{array}{l}\text { Any hypertensive disorder of } \\
\text { pregnancy (81\%), type I } \\
\text { diabetes or nephropathy }\end{array}$ & Any
\end{tabular}

Ramos et al $47 \quad$ Inpatients Gestational hypertension

Ramos et
$1999^{\text {w5 }}$

multiple pregnancy, preterm, prelabour rupture of membranes, stillbirth, or absent fetus

\begin{tabular}{|c|c|c|c|c|c|c|}
\hline $\begin{array}{l}\text { Robert et al } \\
1997^{\text {w6 }}\end{array}$ & 71 & Inpatients & Gestational hypertension & $\geq 24$ & Bacteriuria or diuretic use & 9 \\
\hline $\begin{array}{l}\text { Rodriguez- } \\
\text { Thompson et al } \\
2001^{\text {w7 }}\end{array}$ & 138 & NS & $\begin{array}{l}\text { Any hypertensive disorder of } \\
\text { pregnancy, diabetes mellitus } \\
(3 \%)\end{array}$ & $\geq 29$ & $\begin{array}{l}\text { Urinary tract infection or } \\
\text { chronic medical illness* }\end{array}$ & 9 \\
\hline $\begin{array}{l}\text { Saudan et al } \\
1997^{\text {w8 }}\end{array}$ & 100 & $\begin{array}{l}\text { Inpatients and } \\
\text { outpatients }\end{array}$ & $\begin{array}{l}\text { Any hypertensive disorder of } \\
\text { pregnancy }\end{array}$ & NS & NS & 7 \\
\hline $\begin{array}{l}\text { Taherian et al } \\
2006^{\text {w9 }}\end{array}$ & 100 & NS & $\begin{array}{l}\text { Suspected pre-eclampsia } \\
\text { (gestational hypertension, } \\
\geq 160 / 110 \mathrm{~mm} \mathrm{Hg} \text {, + or more } \\
\text { proteinuria or oedema) }\end{array}$ & $>20$ & $\begin{array}{l}\text { Urinary tract infection, } \\
\text { chronic medical illness, * or } \\
\text { haematuria }\end{array}$ & 11 \\
\hline $\begin{array}{l}\text { Valerio et al } \\
2005^{\mathrm{w} 10}\end{array}$ & $85(75)$ & Inpatients & Gestational hypertension & $>20$ & $\begin{array}{l}\text { Stillbirth, prelabour rupture of } \\
\text { membranes, gestational age } \\
\geq 41 \text { weeks }\end{array}$ & 12 \\
\hline $\begin{array}{l}\text { Wheeler et al } \\
2007^{\mathrm{w} 11}\end{array}$ & $154(126)$ & Inpatients & $\begin{array}{l}\text { Suspected pre-eclampsia } \\
\text { (gestational hypertension, } \\
\text { worsening hypertension, or + } \\
\text { or more proteinuria) }\end{array}$ & $>20$ & $\begin{array}{l}\text { Bacteriuria, bed rest for more } \\
\text { than } 24 \text { hours }\end{array}$ & 11 \\
\hline $\begin{array}{l}\text { Yamasmit et al } \\
2004^{\text {w12 }}\end{array}$ & $55(42)$ & Inpatients & $\begin{array}{l}\text { Suspected pre-eclampsia } \\
\text { (gestational or pre-existing } \\
\text { hypertension with new + or } \\
\text { more proteinuria) }\end{array}$ & $\geq 29$ & $\begin{array}{l}\text { Urinary tract infection or } \\
\text { chronic medical illness* }\end{array}$ & 12 \\
\hline $\begin{array}{l}\text { Young et al } \\
1996^{\text {w13 }}\end{array}$ & $66(45)$ & Inpatients & Gestational hypertension & $\geq 29$ & $\begin{array}{l}\text { Previous diagnosis of } \\
\text { "pregnancy induced } \\
\text { hypertension," or bed rest at } \\
\text { home or in hospital for more } \\
\text { than } 36 \text { hours }\end{array}$ & 10 \\
\hline
\end{tabular}

QUADAS=quality assessment of studies of diagnostic accuracy in systematic reviews based on 14 criteria of study quality; NS=not specified. *Including chronic (pre-existing) hypertension, pregestational diabetes mellitus, or chronic renal disease.

tWomen who were post partum or had vaginal bleeding of another cause and had urine collected through a urinary catheter.

and ranged from 0.82 to $0.97 .^{\text {w1 w2 w7-w13 }}$ A cut-off point for the spot protein:creatinine ratio that maximised both sensitivity and specificity could be identified for nine of the 11 studies. No consistency was found in how cut-off points were reported, and units differed widely (mg/mmol, $\mathrm{mg} / \mathrm{g}, \mathrm{mg} / \mathrm{mg}$, and $\mathrm{g} / \mathrm{g})$. Eight cut-off points were used, with a median of $24 \mathrm{mg} / \mathrm{mmol}$ and a range of 17 to $57 \mathrm{mg} / \mathrm{mmol}(0.15-0.5 \mathrm{mg} / \mathrm{mg})$. The median sensitivity was $91 \%$ (range $73-97 \%$ ) and the median specificity was $90 \%$ (range $41-100 \%$ ). The median positive likelihood ratio was 9.1 (range 1.54 to infinity) and the median negative likelihood ratio was 0.14 (range 0.04-0.37). One study presented a BlandAltman plot to assess agreement between the spot protein:creatinine ratio and 24 hour proteinuria and found good agreement, particularly for a low range of proteinuria $(<0.5 \mathrm{~g} /$ day $){ }^{\text {w8 }}$

\section{Quantitative data synthesis}

Nine studies had the data necessary for the determination of a cut-off point of $30 \mathrm{mg} / \mathrm{mmol}$ (table 4). ${ }^{\text {w1 w2 w5 }}$ w7-w9 w11-w13 Sensitivity and specificity did not seem to be related to the prevalence of significant proteinuria, or the range of proteinuria (table 2). No significant heterogeneity was shown between studies for the new measures of diagnostic accuracy for the cut-off point of $30 \mathrm{mg} / \mathrm{mmol}(\mathrm{P}=0.94)$; in these calculations, 0.99 was used for specificity when reported specificity was $1.00 .^{\mathrm{w} 9}$

Summary measures of diagnostic accuracy were: 
Table 2|Proteinuria and diagnostic test characteristics for spot protein:creatinine ratio in hypertensive pregnant women

\begin{tabular}{|c|c|c|c|c|c|c|}
\hline Study & $\begin{array}{l}\% \text { (No) of women } \\
\text { with proteinuria* }\end{array}$ & $\begin{array}{c}\text { Range of } 24 \\
\text { hour } \\
\text { proteinuria (g/ } \\
\text { day) }\end{array}$ & $\begin{array}{l}\text { Criteria for adequacy of } 24 \\
\text { hour urine collection }\end{array}$ & $\begin{array}{l}\text { Timing of spot } \\
\text { protein:creatinine } \\
\text { ratio relative to } 24 \\
\text { hour urine }\end{array}$ & $\begin{array}{l}\text { First voided } \\
\text { morning urine } \\
\text { tested }\end{array}$ & $\begin{array}{l}\text { Spot protein: } \\
\text { creatinine ratio } \\
\text { range }(\mathrm{mg} / \\
\mathrm{mmol})\end{array}$ \\
\hline Al et al $2004^{\mathrm{w} 1}$ & $21(39 / 185)$ & $0-8.2 \dagger$ & $\begin{array}{l}\text { Urinary creatinine } \geq 10 \mathrm{mg} / \\
\mathrm{kg} / \text { day }\end{array}$ & Before (morning) & No & $0-667 \dagger$ \\
\hline $\begin{array}{l}\text { Durnwald et al } \\
2003^{w^{2}} \dagger\end{array}$ & $76(168 / 220)$ & $0-19 \dagger$ & NS & Before & NS & 0-2991 \\
\hline $\begin{array}{l}\text { Jaschevatzky et al } \\
1990^{\text {w3 }}\end{array}$ & NS & $0.1-9.7 \dagger$ & NS & After & No & $15.2-9552.5$ \\
\hline $\begin{array}{l}\text { Neithardt et al } \\
2002^{\text {w4 }}\end{array}$ & $83(25 / 30)$ & $0.20-26.5$ & NS & During (morning) & NS & $10-2124$ \\
\hline Ramos et al $1999^{\mathrm{w} 5}$ & $55(26 / 47)$ & $0.24-22.3$ & $\begin{array}{l}\text { Urinary creatinine }>0.8 \mathrm{~g} / \\
\text { day }\end{array}$ & Before & NS & NS \\
\hline Robert et al $1997^{\text {w6 }}$ & $41(29 / 71)$ & $0.03-12.6$ & NS & During & No & NS \\
\hline $\begin{array}{l}\text { Rodriguez- } \\
\text { Thompson et al } \\
2001^{\text {w7 }}\end{array}$ & $50(69 / 138)$ & $0-2 \dagger$ & NS & Before & No & $0-170 \dagger$ \\
\hline Saudan et al $1997^{\text {w8 }}$ & NS & NS & NS & $\begin{array}{l}\text { Before (usually } \\
\text { morning) }\end{array}$ & No & NS \\
\hline Taherian et al $2006^{\mathrm{w} 9}$ & $73(73 / 100)$ & $0.1-8.2 \dagger$ & NS & Before & No & 33.9-9186.9 \\
\hline Valerio et al $2005^{\mathrm{w} 10}$ & $51(38 / 75)$ & $0-15 \dagger$ & $\begin{array}{l}\text { Urinary creatinine } \geq 0.6 \mathrm{~g} / \\
\text { day }\end{array}$ & Before (serially§) & NS & $0-9200 \dagger$ \\
\hline $\begin{array}{l}\text { Wheeler et al } \\
2007^{w 11}\end{array}$ & $54(68 / 126)$ & $0.06-10.8$ & $\begin{array}{l}\text { Urinary creatinine }>1 \mathrm{~g} / \text { day } \\
\text { with urine volume }>1 \mathrm{l} \text { day }\end{array}$ & Before & No & $1.1-1661$ \\
\hline $\begin{array}{l}\text { Yamasmit et al } \\
2004^{\text {w12 }}\end{array}$ & $69(29 / 42)$ & $0.70-6.3$ & NS & Before & No & $8-741$ \\
\hline Young et al $1996^{\text {w13 }}$ & $58(26 / 45)$ & $0.10-0.8 \dagger$ & Maternal report & $\begin{array}{c}\text { Before (66\%), after } \\
(34 \%)\end{array}$ & No & 8-103† \\
\hline
\end{tabular}

NS=not specified.

* $0.3 \mathrm{~g} /$ day or more.

tRange abstracted from figure.

fUrinary catheter was used in $89 \%$ of women because they had vaginal bleeding, were post partum, were in active labour, or were taking magnesium sulphate.

§At 8 am to $2 \mathrm{pm}, 2 \mathrm{pm}$ to $8 \mathrm{pm}, 8 \mathrm{pm}$ to $2 \mathrm{am}$, and 2 am to $8 \mathrm{am}$.

sensitivity $83.6 \%(95 \%$ confidence interval $77.5 \%$ to $89.7 \%)$, specificity $76.3 \%(72.6 \%$ to $80.0 \%)$, positive likelihood ratio 3.53 (2.83 to 4.49), and negative likelihood ratio 0.21 ( 0.13 to 0.31 ) (1003 women). When the prevalence of significant proteinuria was varied from 0.25 to 0.75 for one study without known prevalence the pooled sensitivities and specificities did not differ. ${ }^{\text {w8 }}$ Exclusion of one study ${ }^{\text {w2 }}$ that used a catheter for urine collection resulted in a pooled sensitivity of $84.8 \%(78.7 \%$ to $90.8 \%)$ and pooled specificity of $79.1 \%(75.3 \%$ to $82.8 \%)$; results that were similar (809 women). The assays used to measure protein or creatinine were not described in sufficient detail to allow for an analysis of the impact of laboratory methods on the results.

\section{Spot albumin:creatinine ratio}

The two included studies of the spot albumin: creatinine ratio were considered of good quality when the tool for quality of studies on diagnostic tests was used. ${ }^{17}$ A total of 225 women were referred to an obstetric day unit with gestational hypertension ${ }^{\mathrm{w} 15}$ or any pregnancy hypertension. ${ }^{\text {w14 }}$ Seventy seven (45\%) women had proteinuria of $0.3 \mathrm{~g} /$ day or more. ${ }^{\mathrm{w} 15}$ The 24 hour urinary albumin excretion ranged from $0-11.2 \mathrm{~g} /$ day and spot albumin:creatinine ratio from 0.3$640 \mathrm{mg} / \mathrm{mmol} .{ }^{\mathrm{wl}}$ Diagnostic accuracy for the spot albumin:creatinine ratio was excellent when compared with 24 hour proteinuria (cut-off point $2 \mathrm{mg} / \mathrm{mmol}$, sensitivity $94 \%$, specificity $94 \%$, positive likelihood ratio 15.7 , negative likelihood ratio 0.06$)^{\text {w15 }}$ or with 24 hour albuminuria (cut-off point $27 \mathrm{mg} / \mathrm{mmol}$, sensitivity $95 \%$, specificity $100 \%$, positive likelihood ratio infinity, negative likelihood ratio 0.05). ${ }^{\mathrm{w} 14}$ It was not possible to pool the study results for the spot albumin: creatinine ratio because of the different standards used for comparison.

\section{DISCUSSION}

The quantification of proteinuria is central to the investigation of hypertensive pregnant women. Relevant Australasian and international guidelines advocate use of the spot protein:creatinine ratio. ${ }^{34}$ The test is available from any laboratory that determines protein and creatinine concentrations on 24 hour urine collections.

We identified 13 studies (1214 women) of the spot protein:creatinine ratio used in hypertensive pregnant women. Eight different cut-off points were published, which seemed to be quite different, in part because of the variability in the units used for cut-off points for urinary protein and urinary creatinine: $\mathrm{mg} / \mathrm{mmol}, \mathrm{mg}$ / $\mathrm{g}, \mathrm{mg} / \mathrm{mg}$, and $\mathrm{g} / \mathrm{g}$. This was further complicated by the different populations of pregnant women, including 
Table 3 | Reported cut-off points and summary measures of diagnostic accuracy in studies of urinary spot protein:creatinine ratio in hypertensive pregnant women

\begin{tabular}{|c|c|c|c|c|c|c|c|}
\hline \multirow[b]{2}{*}{ Study } & \multicolumn{2}{|c|}{ Reported cut-off point } & \multirow{2}{*}{$\begin{array}{l}\text { Sensitivity } \\
\text { (\%) }\end{array}$} & \multirow{2}{*}{$\begin{array}{l}\text { Specificity } \\
\text { (\%) }\end{array}$} & \multirow{2}{*}{$\begin{array}{l}\text { Area under receiver } \\
\text { operating curve }(95 \% \\
\left.\qquad \mathrm{Cl}^{\star}\right)\end{array}$} & \multicolumn{2}{|c|}{ Likelihood ratio } \\
\hline & $\mathrm{mg} / \mathrm{mg}$ & $\mathrm{mg} / \mathrm{mmol}$ & & & & Positive & Negative \\
\hline Al et al $2004^{w 1}$ & 0.19 & 21 & 85.0 & 73.0 & $0.86(0.80$ to 0.93$)$ & 3.15 & 0.21 \\
\hline Durnwald et al $2003^{\mathrm{w} 2}$ & 0.39 & 44 & 72.6 & 73.1 & 0.80 & 2.70 & 0.37 \\
\hline Ramos et al $1999^{\text {w5 }}$ & 0.5 & 57 & 96.0 & 96.0 & - & 24.00 & 0.04 \\
\hline Robert et al $1997^{\mathrm{w} 6}$ & - & - & 93.0 & 90.0 & - & 9.30 & 0.08 \\
\hline $\begin{array}{l}\text { Rodriguez-Thompson et al } \\
2001^{\text {w7 }}\end{array}$ & 0.19 & 21 & 90.0 & 70.0 & 0.91 (0.87 to 0.96$)$ & 3.00 & 0.14 \\
\hline Saudan et al $1997^{\text {w8 }}$ & 0.27 & 30 & 93.0 & 92.0 & 0.82 & 11.63 & 0.08 \\
\hline Taherian et al $2006^{\mathrm{w} 9}$ & 0.18 & 20 & 86.3 & 100 & 0.94 (0.88 to 0.98$)$ & Infinity & 0.14 \\
\hline Valerio et al $2005^{\mathrm{w} 10}$ & - & - & 91.0 & 90.0 & $0.97 \dagger$ & 9.1 & 0.10 \\
\hline Wheeler et al $2007^{\mathrm{w} 11}$ & 0.21 & 24 & 86.8 & 77.6 & 0.82 & 3.88 & 0.17 \\
\hline Yamasmit et al $2004^{\text {w12 }}$ & 0.25 & 28 & 96.6 & 92.3 & 0.93 & 12.55 & 0.04 \\
\hline Young et al $1996^{\text {w13 }}$ & 0.15 & 17 & 91.0 & 41.0 & 0.86 & 1.54 & 0.22 \\
\hline
\end{tabular}

normotensive women. In this review we included studies that focused only on women with a hypertensive disorder of pregnancy, in whom we believe the spot protein:creatinine ratio has the greatest potential use.

The sensitivities and specificities in the studies of the spot protein:creatinine ratio varied, as expected, by chance alone. We compared diagnostic accuracy results using a cut-off point of $30 \mathrm{mg} / \mathrm{mmol}$ for the spot protein:creatinine ratio, as recommended in published guidelines. ${ }^{34}$ The pooled results were not sensitive to the range of proteinuria or method of urine collection. Overall, the positive likelihood ratio was poor to fair. The negative likelihood ratio, however, was fair to good, suggesting that a spot protein: creatinine ratio of less than $30 \mathrm{mg} / \mathrm{mmol}$ is a reasonable "rule-out" test for proteinuria of $0.3 \mathrm{~g}$ /day or more.

Albumin specific assays are used extensively outside pregnancy for detection of "microalbuminuria"- that is, 0.03-0.3 g/day-because albumin assays are more specific than total urinary protein for kidney disease as a result of diabetes mellitus or hypertension. ${ }^{16} \mathrm{We}$ identified two studies (225 women) that examined use of the spot albumin:creatinine ratio in pregnancy. The test was excellent at diagnosing proteinuria or albuminuria of $0.3 \mathrm{~g} /$ day or more but data are too limited to advocate use of the test in pregnancy.

Strengths and weaknesses of the review

The strengths of our review include our focus on primarily hypertensive pregnant women and pregnant women admitted to hospital (either as inpatients or outpatients in a day assessment unit) who reflect those seen in clinical practice for evaluation of proteinuria. These women had a wide range of proteinuria and a spectrum of pregnancy hypertension seen in clinical practice. We reported favourable diagnostic test characteristics for a cut-off point of $30 \mathrm{mg} / \mathrm{mmol}$, as recommended by international societies. ${ }^{34}$ One study documented no significant change in results when serial urine specimens were analysed over 24 hours. ${ }^{\text {w10 }}$

Our review has limitations. Firstly, we excluded one article published in a language other than English or French. ${ }^{29}$ Secondly, we excluded abstracts as they were unlikely to provide sufficient detail necessary for the review. Thirdly, we have discussed the focus of

Table 4 | New summary measures of diagnostic accuracy for single cut-off point for urinary spot protein:creatine ratio for proteinuria in hypertensive pregnant women

\begin{tabular}{|c|c|c|c|c|c|}
\hline \multirow[b]{2}{*}{ Study } & \multirow{2}{*}{$\begin{array}{c}\begin{array}{c}\text { New cut-off point (mg/ } \\
\text { mmol) }\end{array}\end{array}$} & \multirow[b]{2}{*}{ New sensitivity (\%) } & \multirow[b]{2}{*}{ New specificity (\%) } & \multicolumn{2}{|c|}{ New likelihood ratio } \\
\hline & & & & Positive & Negative \\
\hline Al et al $2004^{\mathrm{w1}}$ & 22.6 & 80 & 74 & 3.08 & 0.27 \\
\hline Durnwald et al $2003^{\mathrm{w} 2}$ & 33.9 & 81.0 & 55.8 & 1.83 & 0.34 \\
\hline Ramos et al $1999^{\text {w5 }}$ & 30 & 94 & 80 & 4.7 & 0.08 \\
\hline $\begin{array}{l}\text { Rodriguez-Thompson et al } \\
2001^{\mathrm{w} 7}\end{array}$ & 30 & 83 & 71 & 2.86 & 0.24 \\
\hline Saudan et al $1997^{\text {w8 }}$ & 30 & 93 & 92 & 11.63 & 0.08 \\
\hline Taherian et al $2006^{\mathrm{w} 9}$ & 22.6 & 80.8 & 100 & Infinity & 0.19 \\
\hline Wheeler et al $2007^{\mathrm{w} 11}$ & 23.7 & 86.8 & 77.6 & 3.88 & 0.17 \\
\hline Yamasmit et al $2004^{\text {w12 }}$ & 31.6 & 93.1 & 92.3 & 12.09 & 0.07 \\
\hline Young et al $1996^{\mathrm{w} 13}$ & 28.3 & 65 & 82 & 3.61 & 0.43 \\
\hline
\end{tabular}


included studies on inpatients; inadequate reporting of completeness of 24 hour urine collection and its use as the traditional comparator for diagnosing proteinuria; and variable laboratory assays for urinary protein, albumin, and creatinine (particularly for urine from pregnant women with its specific proteins that may interfere with immunoassays). Despite these limitations we found no significant heterogeneity between studies in diagnostic accuracy of the spot protein: creatinine ratio. Finally, when we assessed study quality we often found an inadequate description of selection criteria, spectrum of disease, and how the diagnostic test was executed; the standards for the reporting of diagnostic accuracy studies initiative has recently been published and should improve the quality of diagnostic test studies. ${ }^{30}$

We were unable to identify any formal economic evaluation of the spot protein:creatinine ratio or the albumin:creatinine ratio in hypertensive disorders of pregnancy. Although measurement of albumin is generally more expensive than measurement of protein, techniques have been developed to measure albumin in the clinic setting. ${ }^{10}$ Among pregnant outpatients with underlying renal disease a nearly four-fold decrease in cost was reported with use of the spot protein:creatinine ratio and the Cockcroft-Gault formula (to estimate creatinine clearance, not validated for pregnancy) compared with the 24 hour urine collection for proteinuria and creatinine clearance. ${ }^{2231}$ Other potential costs for 24 hour urine collection include admission to hospital (versus same day testing using the spot protein:creatinine ratio or spot albumin: creatinine ratio), laboratory handling time, and greater nursing supervision.

Perhaps the most important limitation of the literature on which this review is based was the status of the 24 hour urine collection as the standard against which all other tests of proteinuria were compared Outside pregnancy the 24 hour urine collection has well documented problems with completeness, timeliness, and ease of performance. In pregnancy, however, problems are increased by the physiological dilation of the ureters (which can hold up to $200 \mathrm{ml}$ of urine) and incomplete bladder emptying as a result of the enlarging uterus, both of which may cause significant collection errors. ${ }^{32}$ These errors can be avoided by adequate hydration to maintain urine flow ( $500 \mathrm{ml}$ fluid to generate a urine flow of $>6 \mathrm{ml} / \mathrm{min}$ ) and standardisation of the technique at the beginning (urine discard) and end of the collection (lying in left lateral recumbency for 45 minutes to remove any partial obstruction of the ureters related to supine or upright posture). Ideally a urinary catheter would be placed, which is impractical, relatively invasive, and may lead to infection. All things considered, these measures to tackle pregnancy specific problems with the 24 hour urine collection are impractical and not generalisable, particularly in the outpatient setting.

It follows from these limitations of the 24 hour urine collection in pregnancy that it should not be the standard against which new measures are evaluated.
The error to which the spot urine sample is susceptible - that is, the potential mild diurnal variation in protein excretion - is likely to be far outweighed by the error associated with 24 hour urine collection. Alternatively, investigators should move directly to validation of the spot protein:creatinine ratio and spot albumin:creatinine ratio against adverse pregnancy outcomes.

\section{Meaning of the review}

The results of this review show that the spot protein: creatinine ratio is a reasonable "rule-out" test for proteinuria of $0.3 \mathrm{~g} /$ day or more, among otherwise healthy women with gestational hypertension with or without proteinuria on dipstick. Although we excluded women with renal disease, the two relevant studies ${ }^{1222}$ were included in a 2003 review that examined pregnancy as a subgroup, and came to a similar conclusion. ${ }^{33}$ Of the 13 included studies in our review, nine did not use the first voided urine sample for the spot protein:creatinine ratio, suggesting that the test is useful throughout the day. Although a morning sample after the first voided urine specimen has been shown to more likely reflect the 24 hour proteinuria outside pregnancy, ${ }^{34}$ studies in pregnancy have been inconsistent in their finding of a diurnal variation of proteinuria, ${ }^{111335}$ and no significant effect of urine specimen timing was seen in pregnancy when serial samples for protein:creatinine ratio were analysed over 24 hours. $^{\text {w10 }}$

The spot protein:creatinine ratio is convenient and timely when laboratories carry out daily analysis of protein and creatinine. As such, women may be able to avoid being admitted to hospital for assessment of proteinuria and be reassessed easily if there are recurrent clinical concerns about evolution of disease. Proteinuria is, however, but one piece of the diagnostic puzzle for suspected pre-eclampsia, for which there are other diagnostic criteria and clinical considerations (for example, other maternal end organ dysfunction and fetal wellbeing). Also, serious complications (including eclampsia) may occur in the absence of proteinuria. ${ }^{36}$

We do not advocate use of the spot protein: creatinine ratio or spot albumin:creatinine ratio for monitoring or quantifying proteinuria in pregnancy. Only at extremes have higher compared with lower levels of proteinuria been associated with higher maternal or perinatal mortality or morbidity, ${ }^{37-41}$ and quantification of proteinuria has not predicted short term maternal renal failure or ongoing proteinuria. ${ }^{40-43}$ The spot protein:creatinine ratio has not been reliable for quantifying proteinuria either outside or during pregnancy. $^{3544}$

\section{Unanswered questions and future research}

Since the late 1990 s many studies have favourably compared the spot urinary protein:creatinine ratio with 24 hour proteinuria, but the spot protein: creatinine ratio has not been widely adopted in obstetric practice. Reasons for this need to be explored. Reasons may include: the nine published cut-off points in four units (making it challenging to have a "gestalt" of 


\section{WHAT IS ALREADY KNOWN ON THIS TOPIC}

Studies have found that the spot protein:creatinine ratio compares favourably with 24 hour urinary protein estimation, the traditional comparator for measuring proteinuria in pregnancy Many cut-off points for detection of proteinuria of $0.3 \mathrm{~g} /$ day or more have been published

\section{WHAT THIS STUDY ADDS}

The 24 hour urine collection should not be the standard against which new measures of proteinuria or albuminuria are compared in pregnancy

The spot urinary protein:creatinine ratio is a reasonable "rule-out" test for significant proteinuria of $0.3 \mathrm{~g} /$ day or more in pregnancy

Information about the spot urinary albumin:creatinine ratio is insufficient to suggest a cut-off point for diagnosis of significant proteinuria in pregnancy

the literature); that only the international and Australasian societies for the study of hypertension in pregnancy have published a cut-off point of $30 \mathrm{mg} /$ mmol for diagnosis of significant proteinuria; and the inherently conservative and medicolegal perspective of obstetric care providers who must not miss a diagnosis of pre-eclampsia and will, therefore, be resistant to abandoning the traditional comparator without robust and compelling evidence.

We have a particular need for information about the validity of the spot protein:creatinine cut-off point of $30 \mathrm{mg} / \mathrm{mmol}$ for detection of adverse pregnancy outcomes, among inpatients and outpatients with suspected pre-eclampsia. Future research should also deal with the impact on test performance of the timing of the spot protein:creatinine ratio and use of various protein and creatinine assays for pregnancy urine, as well as the accuracy of formulas for estimation of creatinine clearance in pregnancy with decreased use of the 24 hour urine collection.

We thank Ruth Milner and Victor Espinosa for statistical advice, Samantha Reineking for help with the literature search, Catherine Halstead for providing information on laboratory methods, and the following authors for additional information about their own studies: M Brown, AB Neithardt, H Nisell, J G Ramos, T L Wheeler, and W Yamasmit.

Contributors: AMC, ELM, and LAM extracted the data. AMC, PVD, and LAM analysed and presented the data. AMC, MAB, PVD, RML, and LAM drafted and edited the manuscript. AMC and LAM are guarantors.

Funding: At the time of the work, AMC was an obstetric medicine fellow funded by the Centre de Recherche Médicale de l'Université de Sherbrooke. LAM has a scholar award from the Michael Smith Foundation for Health Research and an establishment grant from the Child and Family Research Institute of British Columbia. PvD is a new investigator for the Child and Family Research Institute and a senior scholar at the Michael Smith Foundation for Health Research, and has an establishment grant from the Child and Family Research Institute, from which PvD also receives an investigatorship.

Competing interest: None declared.

Ethical approval: not required for this diagnostic meta-analysis of published studies.

Provenance and peer review: Not commissioned; externally peer reviewed.

1 Report of the National High Blood Pressure Education Program Working Group on High Blood Pressure in Pregnancy. Am J Obstet Gynecol 2000;183:S1-22.

2 Helewa ME, Burrows RF, Smith J, Williams K, Brain P, Rabkin SW. Report of the Canadian Hypertension Society consensus conference: 1. Definitions, evaluation and classification of hypertensive disorders in pregnancy. CMA/ 1997;157:715-25.
3 Brown MA, Hague WM, Higgins J, Lowe S, McCowan L, Oats J, et al. The detection, investigation and management of hypertension in pregnancy: executive summary. Aust N Z J Obstet Gynaecol 2000;40:133-8

4 Brown MA, Lindheimer MD, de Swiet M, Van Assche A, Moutquin JM The classification and diagnosis of the hypertensive disorders of pregnancy: statement from the International Society for the Study of Hypertension in Pregnancy (ISSHP). Hypertens Pregnancy 2001;20:IX-XIV.

5 Menzies J, Magee LA, Macnab YC, Ansermino JM, Li J, Douglas MJ, et al. Current CHS and NHBPEP criteria for severe preeclampsia do not uniformly predict adverse maternal or perinatal outcomes. Hypertens Pregnancy 2007;26:447-62.

6 Brown MA, Buddle ML. Inadequacy of dipstick proteinuria in hypertensive pregnancy. Aust N Z J Obstet Gynaecol 1995;35:366-9.

7 Kuo VS, Koumantakis G, Gallery ED. Proteinuria and its assessment in normal and hypertensive pregnancy. Am J Obstet Gynecol 1992;167:723-8.

8 Myers GL, Miller WG, Coresh J, Fleming J, Greenberg N, Greene T, et al. Recommendations for improving serum creatinine measurement: $a$ report from the Laboratory Working Group of the National Kidney Disease Education Program. Clin Chem 2006;52:5-18.

9 Phelan LK, Brown MA, Davis GK, Mangos G. A prospective study of the impact of automated dipstick urinalysis on the diagnosis of preeclampsia. Hypertens Pregnancy 2004;23:135-42.

10 Waugh J, Kilby M, Lambert P, Bell SC, Blackwell CN, Shennan A, et al. Validation of the DCA 2000 microalbumin:creatinine ratio urinanalyzer for its use in pregnancy and preeclampsia. Hypertens Pregnancy 2003;22:77-92

11 Adelberg AM, Miller J, Doerzbacher M, Lambers DS. Correlation of quantitative protein measurements in 8-, 12-, and 24-hour urine samples for the diagnosis of preeclampsia. Am J Obstet Gynecol 2001;185:804-7.

12 Evans W, Lensmeyer JP, Kirby RS, Malnory ME, Broekhuizen FF. Twohour urine collection for evaluating renal function correlates with 24hour urine collection in pregnant patients. J Matern Fetal Med 2000;9:233-7.

13 Rinehart BK, Terrone DA, Larmon JE, Perry KG Jr, Martin RW, Martin JN Jr. A 12-hour urine collection accurately assesses proteinuria in the hospitalized hypertensive gravida. J Perinatol 1999;19:556-8.

14 Somanathan N, Farrell T, Galimberti A. A comparison between 24 hour and 2-hour urine collection for the determination of proteinuria. Obstet Gynaecol 2003;23:378-80.

15 Wongkitisophon K, Phupong V, Yamasmit W, Pansin P, Tannirandorn Y, Charoenvidhya D. Correlation of 4- and 24-hour urine protein in women with initially diagnosed hypertensive disorders in pregnancy. J Med Assoc Thai 2003;86:529-34.

16 Vassalotti JA, Stevens LA, Levey AS. Testing for chronic kidney disease: a position statement from the National Kidney Foundation. Am J Kidney Dis 2007;50:169-80.

17 Whiting P, Rutjes AW, Reitsma JB, Bossuyt PM, Kleijnen J. The development of QUADAS: a tool for the quality assessment of studies of diagnostic accuracy included in systematic reviews. BMCMed Res Methodol 2003;3:25.

18 Deeks JJ. Systematic reviews of evaluations of diagnostic and screening tests. In: Egger M, Davey Smith G, Altman DG, eds. Systematic reviews in health care: meta-analysis in context. London: B M) Books, 2001:248-82.

19 Skweres T, Preis K, Ciepluch R, Miskiewicz K. [The value of a urine protein-to-creatinine ratio assessment in a single voided urine specimen in prediction of 24-hour proteinuria in pregnancy induced hypertension]. Ginekol Pol 2006;77:415-21.

20 Boler L, Zbella EA, Gleicher N. Quantitation of proteinuria in pregnancy by the use of single voided urine samples. Obstet Gynecol 1987;70:99-100.

21 Haas DM, Sabi F, McNamara M, Rivera-Alsina M. Comparing ambulatory spot urine protein/creatinine ratios and 24-h urine protein measurements in normal pregnancies.J Matern Fetal Neonatal Med 2003;14:233-6.

22 Quadri KH, Bernardini J, Greenberg A, Laifer S, Syed A, Holley JL. Assessment of renal function during pregnancy using a random urine protein to creatinine ratio and Cockcroft-Gault formula. Am J Kidney Dis 1994:24:416-20.

23 Zadehmodarres S, Razzaghi MR, Habibi G, Najmi Z, Jam H, Mosaffa N, et al. Random urine protein to creatinine ratio as a diagnostic method of significant proteinuria in pre-eclampsia. Aust N ZJ Obstet Gynaecol 2006; 46:501-4.

24 Yamasmit W, Wongkitisophon K, Charoenvidhya D, Uerpairojkit B, Chaithongwongwatthana $\mathrm{S}$. Correlation between random urinary protein-to-creatinine ratio and quantitation of 24-hour proteinuria in preeclampsia. J Med Assoc Thai 2003;86:69-73.

25 Uttendorfsky OT, Veersema D, Mooij PN, Stolte LA. Protein/creatinine ratio in the assessment of proteinuria during pregnancy. Eur J Obstet Gynecol Reprod Biol 1988;27:221-6. 
26 Risberg A, Larsson A, Olsson K, Lyrenas S, Sjoquist M. Relationship between urinary albumin and albumin/creatinine ratio during normal pregnancy and pre-eclampsia. Scand / Clin Lab Invest 2004;64:17-23.

27 Wikstrom AK, Wikstrom J, Larsson A, Olovsson M. Random albumin/ creatinine ratio for quantification of proteinuria in manifest preeclampsia. Br J Obstet Gynaecol 2006;113:930-4.

28 Kieler H, Zettergren T, Svensson H, Dickman PW, Larsson A. Assessing urinary albumin excretion in pre-eclamptic women: which sample to use? Br J Obstet Gynaecol 2003;110:12-7.

29 Egger M, Dickersin K, Davey Smith G. Problems and limitations in conducting systematic reviews. In: Egger M, Davey Smith G, Altman DG, eds. Systematic reviews in health care: meta-analysis in context. London: BMJ Books, 2001:43-68.

30 Bossuyt PM, Reitsma JB, Bruns DE, Gatsonis CA, Glasziou PP, Irwig LM, et al. Towards complete and accurate reporting of studies of diagnostic accuracy: the STARD initiative. Ann Intern Med 2003;138:40-4.

31 Cockcroft DW, Gault MH. Prediction of creatinine clearance from serum creatinine. Nephron 1976;16:31-41.

32 Lindheimer MD, Katz Al. Renal morphologic and physiologic changes in pregnancy. In: Zuspan FP, ed. Kidney function and disease in pregnancy. Philadelphia: Lea \& Febiger, 1977:1-42.

33 Price CP, Newall RG, Boyd JC. Use of protein:creatinine ratio measurements on random urine samples for prediction of significant proteinuria: a systematic review. Clin Chem 2005;51:1577-86.

34 Ginsberg JM, Chang BS, Matarese RA, Garella S. Use of single voided urine samples to estimate quantitative proteinuria. $N$ Engl J Med 1983;309:1543-6.

35 Lindow SW, Davey DA. The variability of urinary protein and creatinine excretion in patients with gestational proteinuric hypertension. $\mathrm{Br}$ J Obstet Gynaecol 1992;99:869-72.
36 Douglas KA, Redman CW. Eclampsia in the United Kingdom. BMJ 1994;309:1395-400.

37 Chan P, Brown M, Simpson JM, Davis G. Proteinuria in pre-eclampsia: how much matters? Br J Obstet Gynaecol 2005;112:280-5.

38 Ferrazzani S, Caruso A, De Carolis S, Martino IV, Mancuso S. Proteinuria and outcome of 444 pregnancies complicated by hypertension. Am J Obstet Gynecol 1990;162:366-71.

39 Lao T, Chin RK, Lam YM. The significance of proteinuria in preeclampsia; proteinuria associated with low birth weight only in preeclampsia. Eur J Obstet Gynecol Reprod Biol 1988;29:121-7.

40 Newman MG, Robichaux AG, Stedman CM, Jaekle RK, Fontenot MT, Dotson T, et al. Perinatal outcomes in preeclampsia that is complicated by massive proteinuria. Am J Obstet Gynecol 2003;188:264-8.

41 Schiff E, Friedman SA, Kao L, Sibai BM. The importance of urinary protein excretion during conservative management of severe preeclampsia. Am J Obstet Gynecol 1996;175:1313-6.

42 Hall DR, Odendaal HJ, Steyn DW, Grove D. Urinary protein excretion and expectant management of early onset, severe pre-eclampsia. Int J Gynaecol Obstet 2002;77:1-6.

43 Chua S, Redman CW. Prognosis for pre-eclampsia complicated by $5 \mathrm{~g}$ or more of proteinuria in 24 hours. Eur J Obstet Gynecol Reprod Biol 1992;43:9-12.

44 Lane C, Brown M, Dunsmuir W, Kelly J, Mangos G. Can spot urine protein/creatinine ratio replace $24 \mathrm{~h}$ urine protein in usual clinical nephrology? Nephrology (Carlton) 2006;11:245-9.

Accepted: 12 March 2008 